\title{
South American Coccinellidae (Coleoptera). Part X: A systematic revision of Thalassa Mulsant (Hyperaspidinae) ${ }^{1}$
}

\author{
Julianne Milléo²; Lúcia Massutti de Almeida ${ }^{3,5} \&$ Robert D. Gordon ${ }^{4}$
}

\begin{abstract}
${ }^{1}$ Contribution $\mathrm{n}^{\circ} .1437$ of the Departamento de Zoologia, Universidade Federal do Paraná.
2Departamento de Biologia Geral, Universidade Estadual de Ponta Grossa. 84030-000, Ponta Grossa-PR, Brazil. E-mail: jmilleo@hotmail.com ${ }^{3}$ Departamento de Zoologia, Universidade Federal do Paraná. Caixa Postal 19030, 81531-980 Curitiba-PR, Brazil. E-mail:lalmeida@ufpr.br ${ }^{4}$ Northern Plains Entomology, PO Box 65, Willow City, North Dakota, USA. 58384. E-mail: rdgordon@utma.com

${ }^{5}$ Pesquisador do $\mathrm{CNPq}$
\end{abstract}

\begin{abstract}
Resumo. Coccinellidae (Coleoptera) da América do Sul. Parte X: Revisão sistemática de Thalassa Mulsant (Hyperaspidinae). O gênero Thalassa Mulsant, 1850 é revisado. Suas cinco espécies são redescritas: T. pentaspilota (Chevrolat, 1853), $T$. flaviceps Mulsant, 1850, T. similaris Mulsant, 1850, T. montezumae Mulsant, 1850 e T. glauca (Mulsant, 1850). Uma nova espécie é proposta, Thalassa korschefskyi sp. nov., da Colômbia. São fornecidas ilustrações e chave para as espécies. O lectótipo de Thalassa reyi Mulsant, 1850 é aqui designado.
\end{abstract}

Palavras-Chave. Coccinellidae; Hyperaspidini; Taxonomia; Thalassa.

Abstract. The genus Thalassa Mulsant, 1850 is revised. Its five species are redescribed: T. pentaspilota (Chevrolat, 1853), T. flaviceps Mulsant, 1850, T. similaris Mulsant, 1850, T. montezumae Mulsant, 1850, and T. glauca (Mulsant, 1850). A new species is proposed, Thalassa korschefskyi sp.nov., from Colombia. The species are illustrated and a key to species is also provided. Lectotype of Thalassa reyi Mulsant, 1850 is here designated.

Keywords. Coccinellidae; Hyperaspidini; Taxonomy; Thalassa.

Thalassa Mulsant is a small genus of lady beetles thus far known from southern Arizona (USA) to Brazil. The genus is redefined and all species redescribed and illustrated herein.

Mulsant (1850) described Thalassa, placing it in a group he called "Thalassaires" along with Corystes Mulsant, 1850 and Menoscelis Mulsant, 1850. Thalassa was characterized by the emarginate eyes, shape of the anterior frontal margin, and the form of the anterior legs. Mulsant (1850) described six species in the new genus: T. montezumae, T. pentaspilota (Chevrolat) as T. pentastigma, T. flaviceps, T. similaris, T. reyi, and T. prasina.

Свотсн (1874) briefly redescribed five of these species and designated T. pentaspilota (Chevrolat) as the type species. He also synonymized T. reyi with Menoscelis glauca Mulsant (1850) and T.prasina with T.flaviceps.

CHapuis (1876) considered Thalassa as a subgenus of Menoscelis: M. (Menoscelis) and M. (Thalassa).

GoRHAM (1894) considered Menoscelis to be a synonym of Thalassa, followed by KORSCHEFSKY (1931) and BLACKWELDER (1945). Otherwise, Duverger (1989) and FürsCH (1990) placed Menoscelis as a subgenus of Thalassa.

Chapin (1966) presented a key to some genera of "Hyperaspini" in which he included Thalassa, but did not mention Menoscelis, apparently considering the latter to be a synonym of Thalassa.

Gordon (1985) redescribed the genus and the species $T$. montezumae. In 1987 he included five species in Thalassa and designated lectotypes for $T$. similaris and T. pentaspilota.

The specimens examined were provided by the following institutions: National Museum of Natural History, Washington,
D.C. (USNM); University Museum of Zoology, Cambridge (UMZC); The Natural History Museum, London (BMNH); Coleção Entomológica Pe. J. S. Moure, Departamento de Zoologia, Universidade Federal do Paraná, Curitiba, (DZUP); Museu Nacional, Universidade Federal do Rio de Janeiro, Rio de Janeiro (MNRJ).

Thalassa Mulsant, 1850

Thalassa Mulsant, 1850:506; Crotch, 1873:364; 1874:209; Gorham, 1894:183; Korschefsky, 1931:208; Blackwelder, 1945:449; Chapin, 1966:280; Gordon, 1985:400; 1987:26.

Menoscelis (Thalassa); Chapuis, 1876:233.

Thalassa (Menoscelis); Duverger, 1989:146; Fürsch, 1990: 63.

Type species: Chilocorus pentaspilotus Chevrolat, 1835 by subsequent designation of Crotch, 1874.

Body rounded in dorsal view (Fig. 1) convex (Fig. 2). Dorsal surface glabrous. Some species sexually dimorphic.

Eyes finely faceted and glabrous, not emarginate near antennal insertion (Fig. 3). Antennal insertion visible. Antennae short, composed of 11 antennomeres; scape subrectangular, with slight lateral lobe; pedicel rectangular; antennomere 9 three times longer than wide; 10 rectangular, 11 subtriangular (Fig. 4). Clypeus with apical margin slightly arcuate, with straight lateral margins projected (Fig. 3). Labrum subrectangular in shape (Fig. 5). Mandibles symmetrical, large, robust, strongly sclerotized; with apical and subapical incisor teeth and pointed median mola; prostheca with short bristles (Fig. 6). Maxilae sclerotized; palpomere 4 securiform, sides strongly diverging 


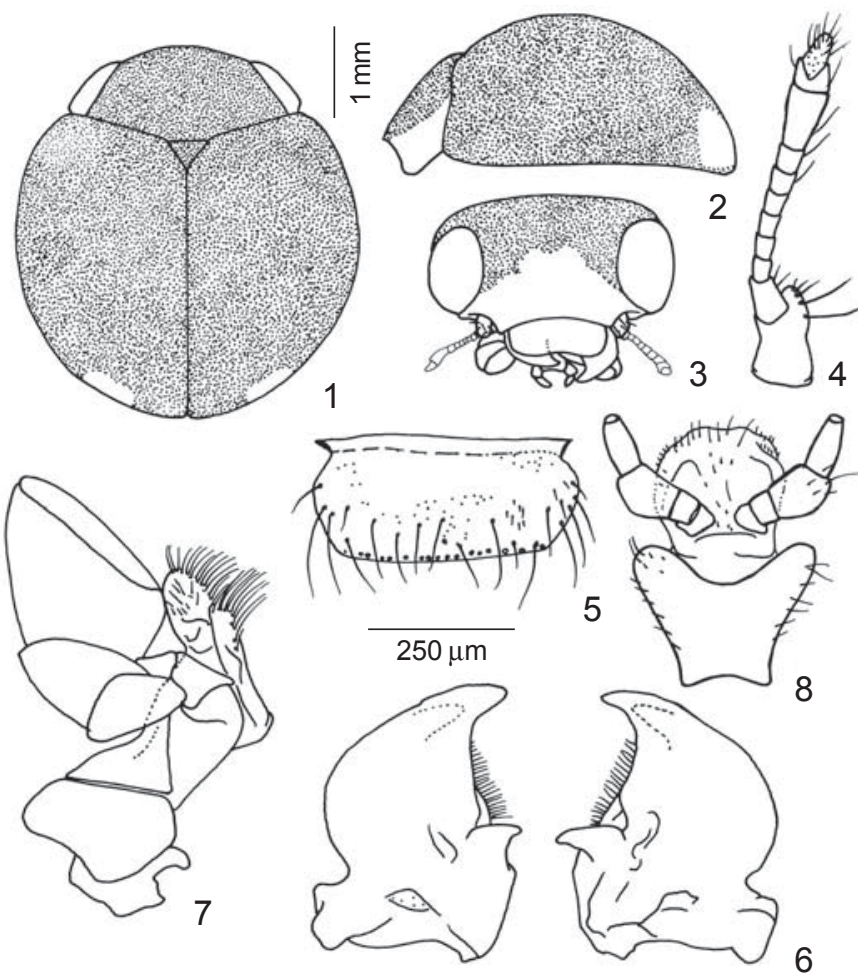

Figs. 1-8. Thalassa pentaspilota: 1, dorsal view; 2, lateral view; 3, head, frontal view; 4, antenna; 5, labrum; 6, mandibles; 7, maxilla; 8, labium.

(Fig. 7). Labium with anterior ligula densely covered with small spines, ventral portion of ligula with several long setae; each labial palpus with basal articles and last narrower in the distal region. Mentum cordiform, prementum truncate; with median area strongly truncate (Fig. 8).

Prosternal process nearly parallel sided; prosternal carinae short, parallel (Fig. 9). Metendosternite trapezoidal, lateral margins almost parallel, with deep V-shaped anterior border (Fig. 10).

Wings with anal venation reduced; $1^{\text {st }}$ and $2^{\text {nd }}$ Anal veins and Ea, Eb and P evident (Fig. 12).

Elytra rounded with raised humeral callosity, lateral margin not flattened (Figs. 1, 2). Epipleura with excavations to receive apices of middle and hind femur (Fig. 11). Anterior tibia slender, with evident projection near apex, strongly excavated to receive tarsus; external basal angle rounded near base (Fig. 13). Tarsomere 2 subtriangular in ventral view; tarsal claw appendiculate (Fig. 14).

Male abdomen with 7 visible segments; female abdomen with 6 visible segments (Fig. 15).

Male genitalia. Median lobe asymmetrical, paramere longer than median lobe. Sipho strongly sclerotized, curved, with elongated apex (Fig. 19).

Female genitalia. Spermatheca globular; wide, transverse coxites with slender setae, without stylus and infundibulum (Fig. 16).

Remarks. Thalassa and Menoscelis have long been considered synonymous (Gorham 1894; KORSCHEFSKy 1931; BLACKWELDER 1945), or treated as subgenera (CHAPUIS 1876; DUVERGER 1989; FürSh 1990). We consider these two genera valid, based primarily on the quite different form of the anterior legs. Thalassa has slender, unmodified tibiae lacking flanges or projections of any type. Menoscelis has wide, highly modified legs of the type usually associated with the genus Hinda Mulsant, 1850 in the tribe Brachiacanthadini. In addition, Thalassa species are relatively small and characteristically dark in color with a metallic tint and yellow or orange spots. Species of Menoscelis are large and basically yellow with reddish brown maculation.

Thalassa is a typical Hyperaspidini genus because the eyes are not emarginated and the female genitalia have globular spermatheca and lack infundibulae. It is most similar to Tiphysa Mulsant, 1850 of the tribe Brachiacanthini because of size and color. Tiphysa differs from Thalassa by having eyes emarginated, and female genitalia with globular spermatheca and lacking an infundibulum (Milléo \& Almeida 2003).

Key to species of Thalassa

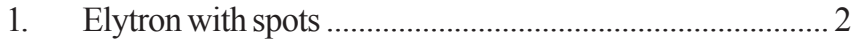

Elytron without spots ........................................................ 4

2(1). Elytron with one small spot .................................................. 3 Elytron with two rounded yellow spots on disc (Figs. 33, 40) Thalassa korschefskyi sp. nov.

3(2). Elytron with one rounded yellow spot near the apex (Fig.1, 35)..... Thalassa pentaspilota (Chevrolat)

Elytron with one quadrangular yellow spot at middle of disc (Figs. 25, 38) ...... Thalassa montezumae Mulsant

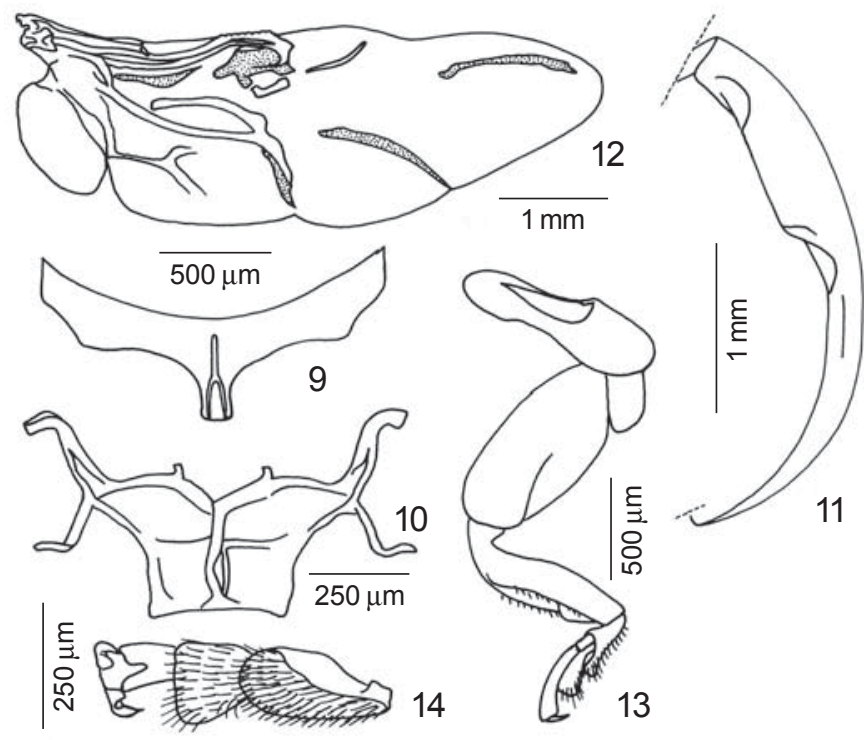

Figs. 9-14. Thalassa pentaspilota: 9, prosternal process; 10, metendosternite; 11, epipleuron, ventral view; 12, wing; 13, anterior leg; 14, tarsus. 


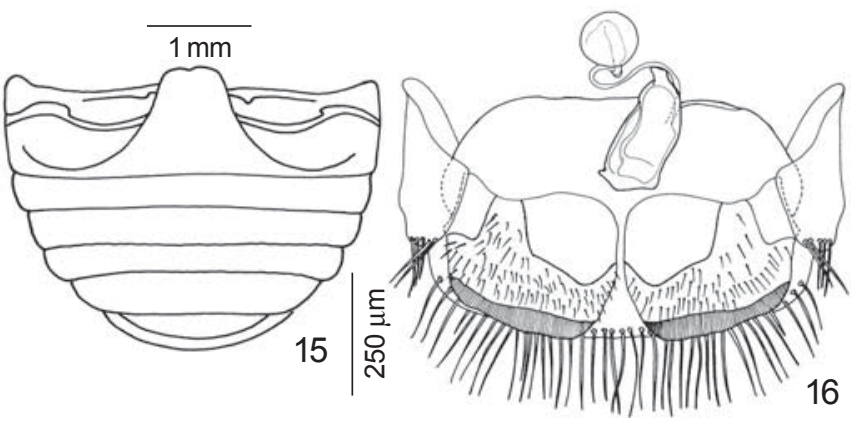

Figs. 15-16. Thalassa pentaspilota: 15, female abdomen; 16, female genitalia.

4(1). Pronotum with lateral margins yellow . .5

Pronotum with anterior and lateral margins narrowly dark yellow (Figs. 21,37) ........ Thalassa similaris Mulsant

5(4). Pronotum broadly yellow on lateral margin. Length 5.17 $5.83 \mathrm{~mm}$. Width 5 - $5.33 \mathrm{~mm}$ (Figs. 17, 36)

Thalassa flaviceps Mulsant

Pronotum with lateral margin narrowly yellow. Length 6.67 mm. Width 6 mm (Figs. 29, 39)

Thalassa glauca (Mulsant)

Thalassa pentaspilota (Chevrolat, 1835)

(Figs.1-16,35)

Chilocorus pentaspilotus Chevrolat, 1835:124; Mulsant, 1850: 103; Gorham, 1894:183; Gordon, 1985:400; Fürsch, 1989:20; 1990:17. Thalassa pentastigma [sic]; Mulsant, 1850:512-513; Crotch, 1874:209. Hyperaspis pentastigma [sic]; Mulsant, 1850:513.

Thalassa pentaspilota; Crotch, 1874:209; Gorham, 1894:183; Blackwelder, 1945:449; Gordon, 1987:26; Duverger, 1989:146.

Coccinella pentaspilota; Crotch, 1874:209.

Thalassa pentaspilotus [sic]; Korschefsky, 1931:209.

Diagnosis. Female. Pronotum, scutellum and elytron bright metallic bluish-green. Dorsum of head and mouthparts black, front of head yellow. Pronotum with lateral margins narrowly yellow. Elytra with one small rounded spot near the apex (Fig.1, 35). Thoracic sterna, abdomen and legs black. Length 4.83 $5.67 \mathrm{~mm}$. Width $4.33-4.83 \mathrm{~mm}$.

Male. Not examined.

Female genitalia. Coxites subquadrates, sparsely setose, bursa copulatrix elongate, spermatheca rounded (Fig. 16).

Type material. The lectotype of Chilocorus pentaspilotus, from Mexico, designated by Gordon (1987), was studied and is located at the University Museum of Zoology, Cambridge, England (UMZC). The specimen has the following labels: [TYPE] in blue, [TYPE Pentastigma Mex] in the reverse [Chevrol.], [Lectotype Thalassa pentastigma Muls. By R.Gordon'70], [Lectotype Thalassa pentaspilota Chevr. 1835 Gordon 1987].

Specimens examined. MEXICO. 1 specimen, B.C.A. Col. VII (BMNH) . VENEZUELA. 2 specimens, Aragua: Boca Del Rio (USNM); 1 specimen, Carabobo: Marciara, (USNM); 1 specimen, Yuma (USNM).
Thalassa flaviceps Mulsant, 1850

(Figs.17-20,36)

Hyperaspis flaviceps Dejean, 1836: 435 (nom. nud.).

Thalassa flaviceps Mulsant, 1850:513; Crotch, 1874:209; Korschefsky, 1931:208; Blackwelder, 1945:449; Gordon, 1987:26.

Thalassa prasina Mulsant, 1850:516; Korschefsky, 1931:208 (syn.).

Thalassina [sic] prasina; Crotch, 1874:209.

Diagnosis. Pronotum, scutellum and elytra bright metallic greenish-blue. Male head yellow, labrum black. Male pronotum with lateral margins narrowly dark yellow. Female pronotum entirely greenish blue. Elytra without maculation (Fig. 17, 36). Thoracic sterna black, abdomen castaneous. Legs black, except outer margin of femur yellow. Length $5.17-5.83 \mathrm{~mm}$. Width 5 $5.33 \mathrm{~mm}$.

Male genitalia. Median lobe with lateral margin angular. Paramere wide with slight constriction at base. Basal piece wide, with short setae (Fig. 18). Sipho strongly sclerotized, sinuate, with membranous apex (Fig. 19).

Female genitalia. Coxites subtriangular, sparse setae near apex, bursa copulatrix slightly rounded; spematheca rounded (Fig. 20).

Type material. The syntype of Thalassa flaviceps from Cuba was not examined and GorDon (1987) indicated, with doubt, that the material should be located at the Muséum d'Histoire Naturelle, Lyon, France.

Specimens examined. CUBA. San Antonio de Las Banos, 28.VI.1928, Bierig leg., 1 specimen (DZUP); Santiago de las Vegas, 1.IV.1938, J.F. leg., 4 specimens (MNRJ); 1 specimen (UMZC). Without locality, 2
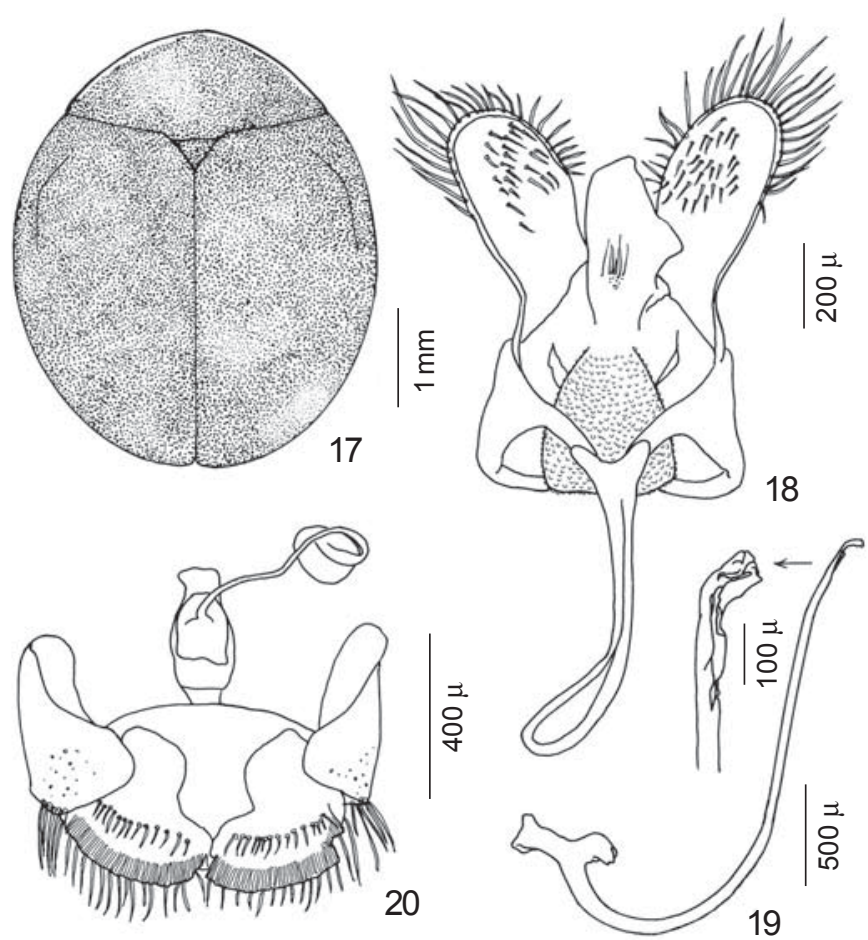

Figs. 17-20. Thalassa flaviceps: 17, dorsal view; male genitalia: 18, tegmen; 19, sipho; 20, female genitalia. 


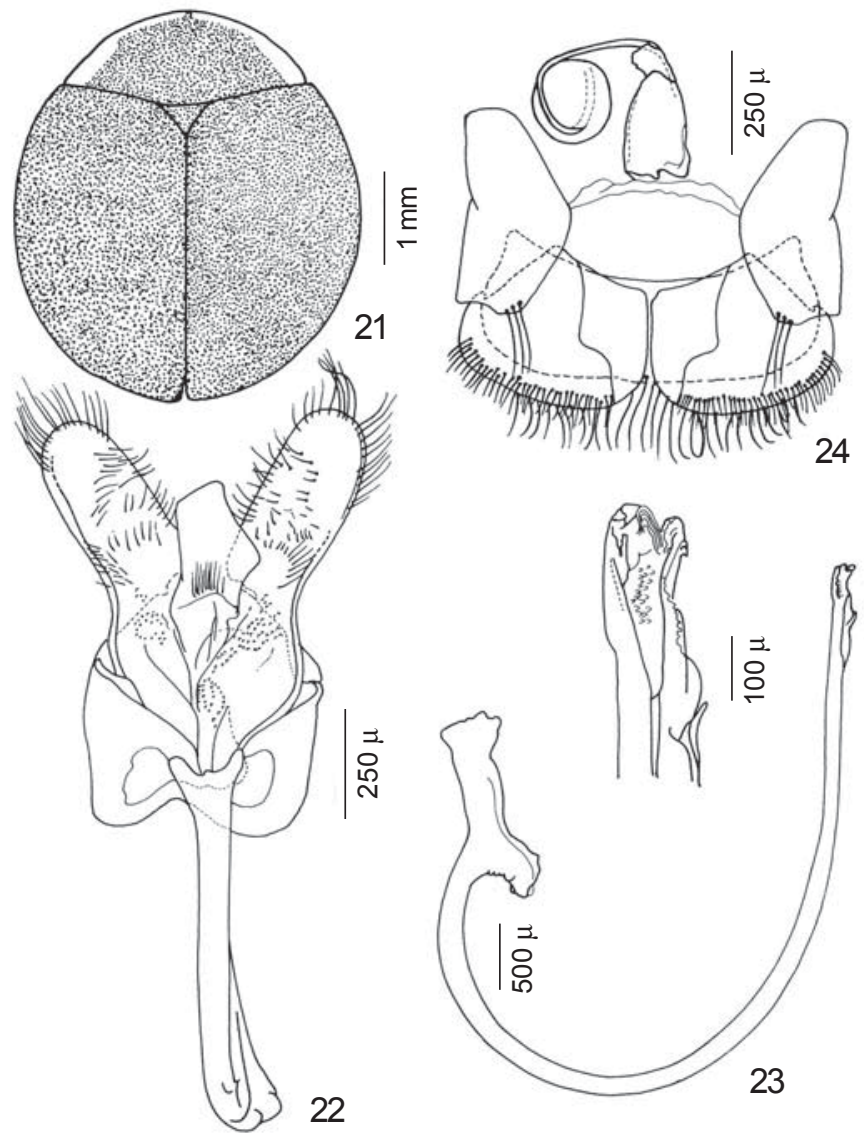

Figs. 21-24. Thalassa similaris: 21, dorsal view; male genitalia: 22, tegmen; 23, sipho; 24, female genitalia.

specimens, Col. Guérin (UMZC); 2 specimens, Col. Chevrolat (UMZC); 1 specimen, Col. Deyrollei (UMZC).

\section{Thalassa similaris Mulsant, 1850}

(Figs. 21-24, 37)

Thalassa similaris Mulsant, 1850:514; Crotch, 1874:209; Korschefsky, 1931:209; Blackwelder, 1945:449; Gordon, 1987:26.

Diagnosis. Dorsum greenish-blue with bright metallic green tint. Male head yellow. Female head with dorsum black, front dark yellow, labrum brown. Male pronotum with anterior and lateral margins narrowly dark yellow. Female pronotum with lateral margins narrowly dark yellow. Elytra without maculation (Fig. 21, 37). Thoracic sterna black, legs yellow, except coxae black. Abdomen yellow with basal portion of basal sternum black. Length 6 a $6.33 \mathrm{~mm}$. Width 5.5 a $6.67 \mathrm{~mm}$.

Male genitalia. Median lobe with lateral margin angular. Paramere and basal piece wide (Fig. 22). Sipho strongly sclerotized and anteriorly curved, membranous apex with small setae (Fig. 23).

Female genitalia. Coxites subquadrangular, with sparse setae near apex, bursa copulatrix slightly elongated; spematheca rounded (Fig. 24).
Type material. The lectotype of Thalassa similaris, from Colombia (Nova Granada), was designated by Gordon (1987). It was studied and is located at the University Museum of Zoology, Cambridge, England (UMZC). The specimen has the following label: [TYPE] in blue, [TYPE similaris N.Gr. Guer.], [Lectotype Thalassa similaris Muls. By R.Gordon'70], [Lectotype Thalassa similaris Muls. 1850 Gordon 1987].

Specimens examined. Without locality, 1 specimen, Col. Deyrolle (UMZC).

\section{Thalassa montezumae Mulsant, 1850}

(Figs.25-28, 38)

Thalassa montezumae Mulsant, 1850:512; Crotch, 1873:364; 1874:209; Gorham, 1894:183; Leng, 1903:211; Korschefsky, 1931:209; Blackwelder, 1945:449; Gordon, 1985:400-401; 1987:26.

Diagnosis. Dorsum bright metallic bluish-green. Male head yellow with brown labrum. Pronotum with anterior and lateral margins narrowly yellow. Elytra with two quadrangular yellow spots on middle of disc (Fig. 25, 38). Thoracic sterna and legs dark brown. Abdomen yellow. Length $6.83 \mathrm{~mm}$. Width $5.67 \mathrm{~mm}$.

Male genitalia. Median lobe with lateral projection. Paramere and basal piece wide, with small setae (Fig. 26). Sipho strongly sclerotized, curved toward apex, apex membranous (Fig. 27).

Female genitalia. Coxites subquadrangular, with sparse bristles near apex, bursa copulatrix slightly elongated; spematheca rounded (Fig. 28).
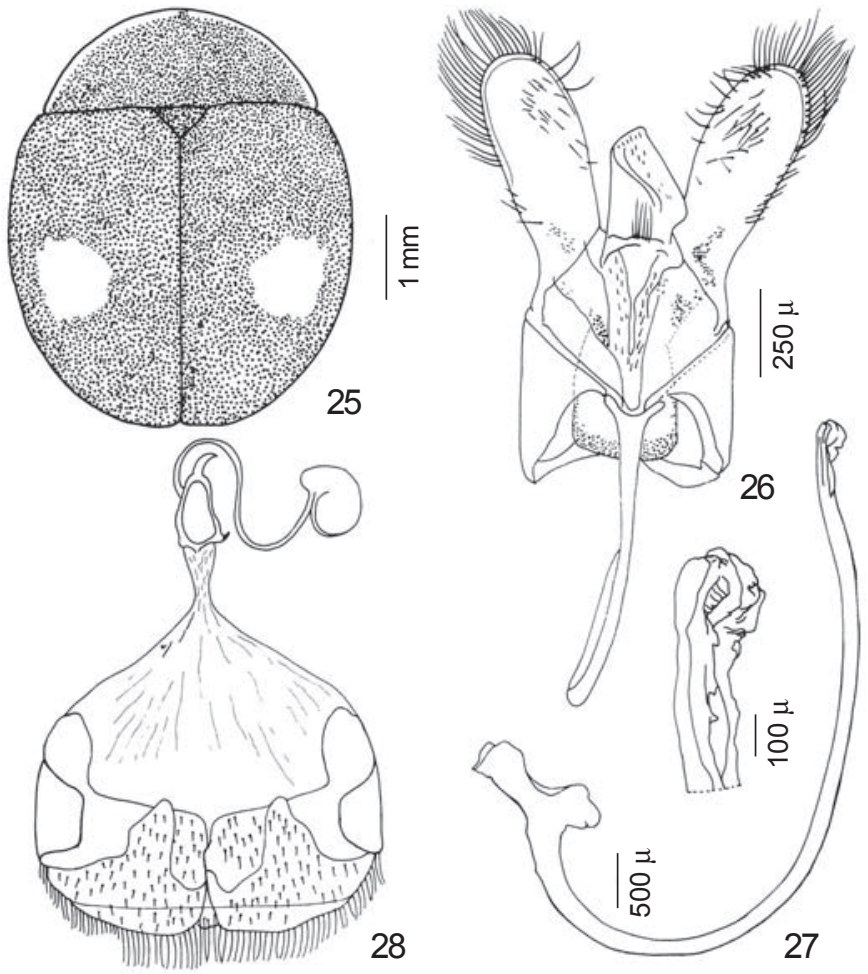

Figs. 25-28. Thalassa montezumae: 25, dorsal view; male genitalia: 26, tegmen; 27, sipho. 28, female genitalia (according to Gordon 1985). 


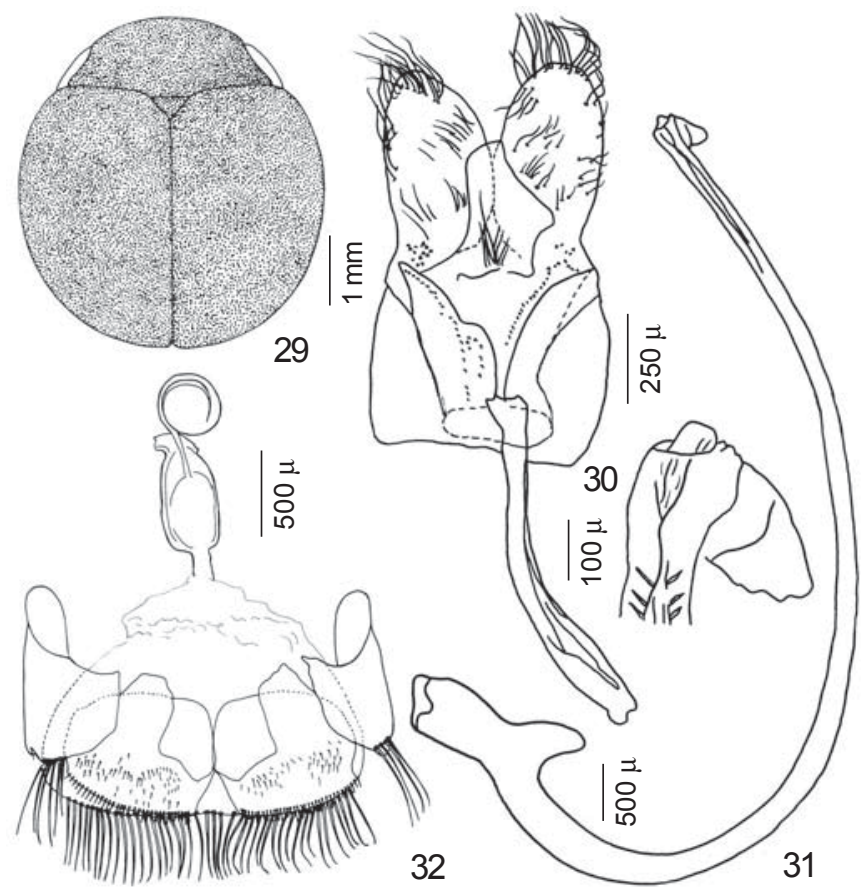

Figs. 29-32. Thalassa glauca: 29, dorsal view; male genitalia: 30, tegmen; 31, sipho; 32, female genitalia.

Type material. The lectotype and the paralectotype of Thalassa montezumae, from Mexico, were designated by GoRdon (1985). They were studied and are located in the University Museum of Zoology, Cambridge, England (UMZC). The lectotype with the following labels: [TYPE] in blue, [TYPE montezumae Mex.] versus [Chevrol], [Lectotype Thalassa montezumae Muls. By R.Gordon'70], [Lectotype Thalassa montezumae Muls. 1850 Gordon 1985]. The paralectotype with the labels: [male] versus [Chevr], [Paralectotype Thalassa montezumae Muls. 1850 Gordon 1987].

Specimens examined. UNITED STATES OF AMERICA. Arizona: 1 specimen (BMNH); Phoenix, J.H.O'Dell leg., 1 specimen (DZUP). MÉXICO. Veracruz, Sallé leg., 1 specimen, B.C.A. col. VII (BMNH); (Playa Vicente), Sallé leg., 1 specimen, B.C.A. col. VII (BMNH); Jalapa, Hoege leg., 1 specimen (BMNH); Puebla, Matamoros Izucar, Hoege leg. 1 specimen (BMNH). GUATEMALA. El Repozo, Champion leg., 1 specimen (BMNH).

Thalassa glauca (Mulsant, 1850)

(Figs. 29-32, 39)

Menoscelis glauca Mulsant, 1850:510-511.

Thalassa glauca; Crotch, 1874:209; Chapuis, 1876:234; Gorham, 1894:184; Korschefsky, 1931:208; Blackwelder, 1945:449; Gordon, 1987:26.

Thalassa reyi Mulsant, 1850:515; Crotch, 1874:209 (syn.).

Diagnosis. Dorsum greenish-blue with bright metallic greenish tint. Male head yellow, in the female with vertex black, front dark yellow, labrum brown. Pronotum with lateral margins narrowly dark yellow. Elytra immaculate (Fig. 29, 39). Thoracic sterna black, legs yellow except coxae and anterior femur black. Abdomen yellow with basal region black. Length $6.67 \mathrm{~mm}$. Width $6 \mathrm{~mm}$.
Male genitalia. Median lobe with lateral projection. Paramere and basal piece wide, with small setae (Fig. 30). Sipho strongly sclerotized, curved toward apex, apex with membranous lateral projection (Fig. 31).

Female genitalia. Coxites subquadrangular, with sparse setae near apex and external surface; bursa copulatrix elongated; spematheca rounded (Fig. 32).

Remarks. T. glauca and T. similaris are quite similar and possibly synonymous.

Type Material. Menoscelis glauca Mulsant was described from the Dupont collection, but type has not been examined. Gordon (1987) indicated, with doubt, that the material should be located in the Muséum d'Histoire Naturelle, Paris, France.

The syntype of Thalassa reyi Mulsant, from Brazil was studied and is located in the Natural History Museum, London, England (BMNH) with the followings labels: [TYPE] in orange, [57 71] in blue, [119], [Reyi Muls. Brésil.], [named by Mulsant]. To preserve stability of nomenclature, this specimen is here designated LECTOTYPE, and a characteristic label will be added.

Specimens examined. GUATEMALA. Guatemala, Champion leg., 1 specimen, B.C.A. col. VII (BMNH); Tepan, Conradt leg., 1 specimen, B.C.A. col. VII (BMNH); Sallé leg., 1 specimen, B.C.A. col. VII (BMNH). COSTA RICA. Van Patten leg., 1 specimen, B.C.A. col. VII (BMNH). COLÔMBIA. Hoege leg., 46-20, 1 specimen (BMNH). BRASIL. Without locality, 1 specimen, P.Co., Col. Buquet (UMZC). São Paulo: São Paulo (Cantareira), 25.II.1962, J. Halik leg., Halik Collection, 1 specimen, 2029056 (USNM); Jaú, X.1903, 1 specimen, 2029056 (USNM).

\section{Thalassa korschefskyi sp. nov.}

(Figs. 33, 34, 40)

Diagnosis. Dorsum bright metallic bluish-green with four rounded yellow spots. Male head black with two rounded yellow spots. Pronotum with lateral margin narrowly yellow. Elytra with two rounded yellow spots on the disc (Fig. 33, 40). Thoracic sterna, legs and abdomen yellow, except prosternal carinae, brown. Length $4.67 \mathrm{~mm}$. Width $3.75 \mathrm{~mm}$.

Male genitalia. Not examined.

Female genitalia. Coxites subquadrangular, with sparse bristles spoon-like near apex, bursa copulatrix slightly elongated; spematheca rounded (Fig. 34).

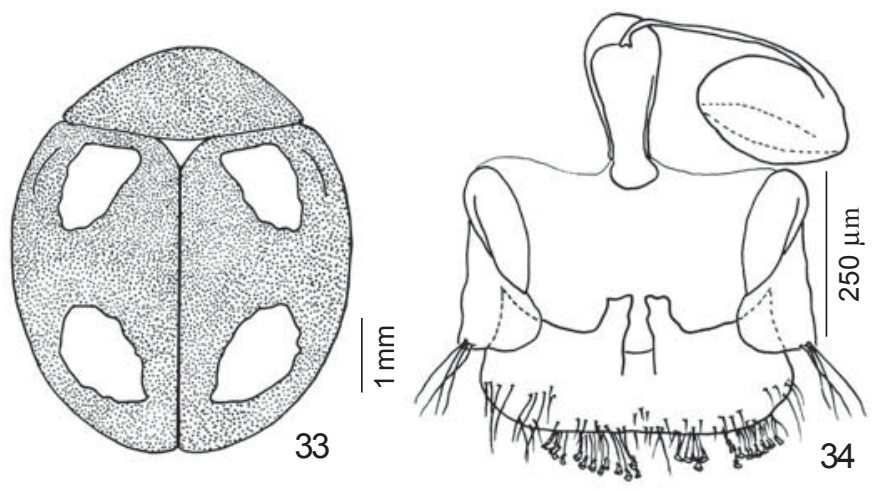

Figs. 33-34. Thalassa korschefskyi sp. nov. holotype female; 33, dorsal view; 34, female genitalia. 

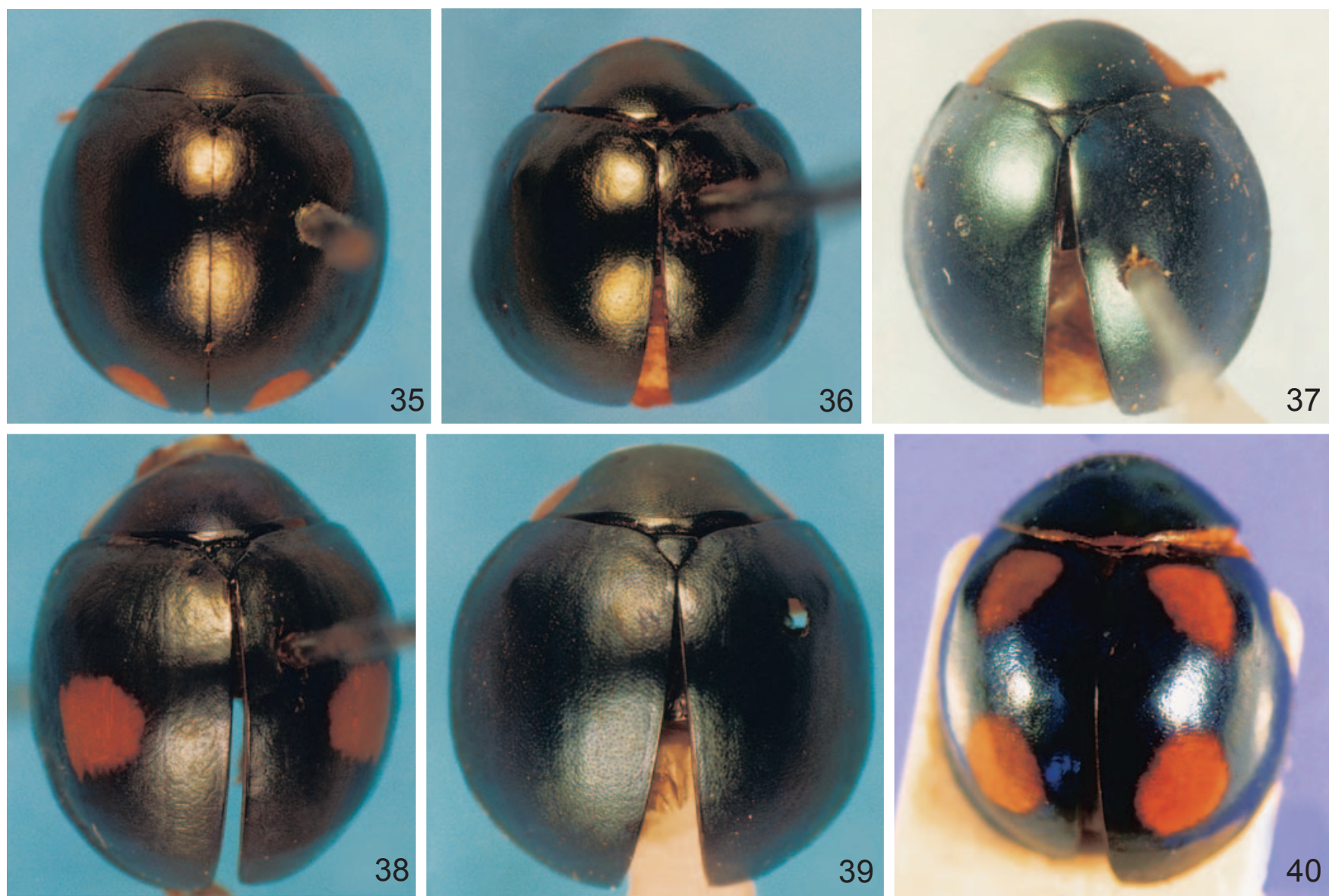

Figs. 35-40. 35, Thalassa pentaspilota; 36, Thalassa flaviceps; 37, Thalassa similaris; 38, Thalassa montezumae; 39, Thalassa glauca; 40, Thalassa korschefskyi sp. nov.

Type material. Holotype female, Colombia, IV-VI. 1908, Hac. Pehlke \& E. Pehlke S., Korschefsky collection, USNM 2029056, deposited in the National Museum of Natural History, Washington, D.C. (USNM).

Remarks. Thalassa korschefskyi is similar to T. pentaspilota but differs in the number and position of the spots on disc of the elytra.

\section{REFERENCES}

Blackwelder, R. E. 1945. Checklist of the Coleopterous Insects of Mexico, Central America, the West Indies, and South America. Bulletin of the United States Natural History Museum 185(3): 343-550. Chapin, E. A. 1966. A new species of myrmecophilous Coccinellidae with notes on other Hyperaspini (Coleoptera). Psyche 73: 278-283.

Chapuis, F. 1876. In: Histoire naturelle des insectes. Genera des Coléoptères. Paris, 12: 1-424.

Chevrolat, L. A. 1835. Coléoptères du Mexique. [Fasc. 5] Strasbourn, $68 \mathrm{p}$.

Crotch, G. R. 1873. Revision of Coccinellidae of the United States. Transactions of the American Entomological Society 4: 363382 .
Crotch, G. R. 1874. A revision of the Coleopterous Family Coccinellidae. London, E. W Janson, $311 \mathrm{p}$.

Dejean, P. F. M. A. 1836.Catalogue des Coléoptères de la Collection de M. le comte Dejean. $2^{\text {nd }}$ Edition. 5. Paris, $443 \mathrm{p}$.

Duverger, C. 1989. Contribution à l'étude des Hyperaspinae $1^{\text {ère }}$ note. Bulletin the la Societé Linneane Bordeaux 17(3): 143-157.

FüRSCH, H. 1989. Newsletter for Systematic research in Coccinellids. Universitàt Passau 1(1). 1-42.

FüRSCH, H. 1990. Newsletter for Systematic research in Coccinellids. Universitàt Passau 2(1): 1-63.

Gordon, R. D. 1985. The Coccinellidae (Coleoptera) of America North of Mexico. Journal of the New York Entomological Society 93(1): 352-599.

Gordon, R. D. 1987. A catalogue of the Crotch collection of Coccinellidae (Coleoptera). Occasional Papers on Systematic Entomology 3: 1-46.

Gorham, H. S. 1894. In: Biologia Centrali-Americana, Insecta, Coleoptera, Coccinellidae 7: 177-208.

Korschefsky, R. 1931. Coccinellidae I. In: Coleopterorum Catalogus. Berlin, W. Junk, 118: 1-224.

Milléo, J. \& L. M. Almeida. 2003. Revision of the Genus Tiphysa Mulsant (Coleoptera, Coccinellidae, Hyperaspidinae). Coleopterists Bulletin 57(3): 274-280.

Mulsant, E. 1850. Species des coléoptères triméres sécuripalpes. Annales des Sciences Physiques et Naturelles de Lyon 2: 1-1104. 